\title{
The Demise of the Únětice Culture due to the Reduced Availability of Natural Resources for Bronze Production
}

\author{
Serge Svizzero $^{1}{ }^{*}$, Clement A. Tisdell ${ }^{2}$ \\ ${ }^{I}$ Faculté de Droit et d'Economie, Université de La Réunion, 15 Avenue René Cassin. CS 9003, 97744 Saint \\ Denis, France \\ ${ }^{2}$ School of Economics, The University of Queensland, St Lucia, 4072, Queensland, Australia
}

*Corresponding Author: Serge Svizzero, Faculté de Droit et d'Economie, Université de La Réunion, 15 Avenue René Cassin. CS 9003, 97744 Saint Denis, France. Email: serge.svizzero@univ-reunion.fr

\begin{abstract}
After a long period of prosperity, the Únétice (2300-1600 B.C.) - a Central European Early Bronze Age culture - collapsed in few decades without obvious reason. Since Unétice was the first bronze metalworkers of Central Europe, we examine whether the reduced availability of bronze could have triggered this social collapse. We claim that it could have been so and provide a detailed analysis of two complementary reasons related to shortages of inputs - placer tin and fuel wood - used to produce bronze which could explain the demise of bronze production and the social collapse of the Únétice culture.
\end{abstract}

Keywords: Early Bronze Age, Social and Cultural Collapse, Únětice Culture, Tin Bronze, Unsustainable Development.

\section{INTRODUCTION}

The Únětice culture (UC) (2300-1600 B.C.) was present during the Early Bronze Age (EBA) over a vast territory of present-day Central Europe. As any EBA culture its economy was mainly dependent on agriculture, the latter being based on crop cultivation and livestock husbandry (Bartelheim, 2009). UC was also characterized by the development of economic activities not related to agro-pastoralism, such as pottery making, interregional trade and metalworking (Szeverenyi, 2004). The latter activity is not unimportant since people of the UC were the first bronze metalworkers of Central Europe. The development of these agricultural and industrial activities allowed the UC to thrive for seven centuries, as evidenced by the size of their settlements and the numerous luxury items (such as gold, amber, bronze ornaments...) found in some of their graves. Such prosperity can be attributed to the economic activities undertaken by people of the UC.

In a relatively short period of time (a few decades or so), societies which had adopted the UC collapsed. They disappeared, leaving no more than an archaeological record. There is no obvious explanation for this collapse. Various - some complementary - explanations of this mysterious collapse have been proposed in the academic literature. As for other social collapses of the past, many explanations are related to cultural factors (Drews, 1993) and their possible negative impact on the environment (Diamond, 2005). Changed trade routes have also been proposed as a possible explanation for the collapse of the UC (Czebreszuk, 2007; De Navarro, 1925; Ekholm, 1980; Ernée, 2012; Jaeger, 2012). Some other scholars (Bátora et al., 2012; Kneisel, 2012; Müller, 2012; Tisdell and Svizzero, 2018) have emphasized the role of environmental deterioration as a cause and/or a marker of the collapse, and have identified important correlations between the two.

Because bronze production had significant social, cultural and economic consequences for chiefdoms adopting the UC, we aim to consider whether lack of sustainability of bronze production was a major contributor to the collapse of this culture and how it contributed to this collapse. A second purpose is to identify factors (mainly economic ones associated with resource depletion) which resulted in the production of bronzes (by followers of the UC) becoming unsustainable. The economic consequences of this, such as their reduced involvement in interregional trade and altered trade routes, will also be examined, as well as social and cultural effects. In section 2 we describe the main features of the UC. In section 3 we explain why the demise of bronze production might have triggered the collapse of the 
UC. We stress three complementary reasons: one is associated with changed trade routes, another is linked to the socio-economic turmoil induced by the crisis of the bronze sector, and the last one is related to the socio-cultural changes, especially the fact that the Unerticean elite could have lost most of its privileges. The bulk of the paper is focused on two complementary reasons which might explain the demise of the bronze production. On the one hand (sections 4 to 7), bronze production depends on the environment because the sources of the metals used can be exhausted after a while (Bouzek, et al., 1989; Cathro, 2005) or become increasingly scarce. On the other hand, (sections 8 and 9), metalworking activities impact the regional vegetation in various ways. In particular, there was a high demand for wood for different purposes (construction, mining), and especially for fuel (charcoal) required by the smelting process (Harding, 2000: 217, Bartelheim, 2013: 175-176). This led to deforestation, soil erosion and finally collapse, as exemplified, for instance, by consequences of the prehistoric exploitation of copper on the island of Cyprus (Constantinou, 1992). It is also relevant to note that Tisdell and Svizzero (2018) have identified problems associated with maintaining the level of agricultural production as a major contributor to the decline in the UC population (at least in Silesia, as documented by Pokutta, 2013) and the eventual speedy disappearance of the affected populations. This undermined the economic prosperity of the affected UC communities and significantly reduced their populations, probably as result of net migration. Furthermore, it reduced the available agricultural surplus for supporting those engaged in bronze-making activities, many of whom then had to seek alternative means of earning and livelihood. (see Tisdell and Svizzero, 2015). The extent to which this caused economic disruption would have depended upon how much of the labor force was involved in metallurgical production and the rapidity of the fall in the agricultural surplus. In Silesia, factors resulting in a decline in the agricultural surplus occurred during the postclassical period of the UC. They occurred contemporaneously with the growing scarcity of bronzes, especially tin bronzes. Consequently several UC chiefdoms came under increasing adverse pressures from two central pillars of their societies at much the same time. Given the interconnections between all UC communities, possibly all UC groups experienced some negative spillover effects from such developments.

\section{2. ÚNĚTice Culture, the First Bronze Metalworkers in Central Europe}

Únětice (2300-1600 B.C.) is a well-known Central European culture of the EBA (Harding, 2000). The most widely used periodisation of Únětice culture consists of six phases ${ }^{1}$ (Moucha, 1963). The first four phases - proto, early, middle and pre-classical - form the early Únětice culture and the "classical and post-classical" the late. Únětician were present over a large area of Central Europe (Müller, 2012, p. 258), spanning from Central Germany to South Poland - between the Harz mountains and the Warta river - and centered on the current German-Czech border, and therefore experienced considerable differences in local environmental and related conditions. The pattern of settlement closely follows natural geographical features, with northern and southern branches of the culture that can be roughly distinguished. They are separated from each other (by the highlands of the Thuringian forest, Erzgebirge and Sudeten mountains) and this created smaller settlement regions that to some extent develop along independent lines. It evolved from the Bell Beaker culture, adopters of which were already using copper, and originated in the territories of contemporary Bohemia (Pare, 2000: 2). Ten local sub-groups can be distinguished in its classical phase. ${ }^{2}$ Despite the diversity of UC, all subgroups shared some common features and it is thus possible to talk about a "culture". The latter is characterized by graves (flat graves and barrows, including the so-called "princely graves"), burials and funerary practice ${ }^{3}$ (which are also indicative of considerable socio-economic inequality), potteries, settlements (especially fortified settlements; Bátora, 2009). Like most cultures of the Bronze Age, the Únětice society was stratified and hierarchical (Bartelheim, 2009). These vertical social differences are mainly reflected in elaborate burials that may include massive stone constructions requiring investment of a large amount of resources and energy, coffins, and exotic grave goods. They are also reflected in the emergence of fortified sites, usually along river valleys (Bàtora, 2009). It

\footnotetext{
${ }^{1}$ It is used in Bohemian archaeology while five phases only are considered in Central Germany.

${ }^{2}$ Bohemia, Moravia, Slovakia (following the Nitra group), lower Austria, central Germany, lower Saxony, lower Lusatia, Silesia, greater Poland and Galicia (western Ukraine).

${ }^{3}$ Burial rite displays strong uniformity; deceased were buried always in north-south alignment, with head facing east, and the body was lying in a "crouched" position.
} 
seems that access to, and control of, metal sources and prestige items circulating in exchange networks became sources of political and economic control from the EBA onwards (Earle, 2002; Kristiansen and Larsson, 2005).

\subsection{Metallurgical Knowledge and Production}

Among all the features defining the UC, the main one is that Unětice people were the first bronze metalworkers in Central Europe (Roberts et al., 2009). The Únětice culture is distinguished by its characteristic metal objects including ingots, torcs, flat axes, flat triangular daggers, bracelets with spiral-ends, disk and paddled headed pins and curl rings which are distributed over a wide area. Indeed, numerous metal items - especially those made of bronze - have been found in graves, hoards and settlements inside the Únĕtician territory (Tylecote, 2002: 30; Jaeger et al., 2015) and also far beyond it, e.g. in Scandinavia, surely as a result of long-distance trade (Szeverenyi, 2004: 25).

Únětician people obtained knowledge about metallurgy either by cultural diffusion and/or by migration. They were located at the convergence of the two streams of migration and cultural influences. One was from southeast Europe (Carpathians and the Balkans), where the earliest artefacts made of native copper and copper minerals are known from the Early to the Middle Neolithic (Kienlin, 2013: 416) and where the Bronze Age began around 3000 B.C.. The other influence was from western Europe, namely the Bell Beaker ${ }^{4}$ culture which was initiated in Iberia (Merkl, 2010). Indeed, the re-emergence of metallurgy in Central Europe is linked to various regional groups of the Corded Ware and Bell Beaker cultures that were later replaced by UC.

UC groups were present over a vast and heterogeneous geographical territory. Thus some groups could have direct access to metal ores located on their own territory while others were constrained to trade metal ores with neighboring tribes. While it seems certain that all tribes had their own metalworking centers (Szeverenyi, 2004: 24), even when no raw materials were locally available, they were not necessarily involved in all stages of the bronze production process (Ottaway and Roberts, 2008: 214).

\section{Consequences of the Reduced Availability of Natural Resources for Producing BRONZE}

In this section we consider two main aspects of the increased scarcity of natural resources for producing bronzes. These are its significant economic consequences and its likely socio-cultural impacts on UC tribes. It is pertinent to note in advance that the principal purpose of bronze production in the EBA was for the production of prestige items (Szeverenski, 2004 : 24-25; Bartelheim, 2009, 2013), such as ornaments. It was only in the middle of the Bronze Age that significant use of bronzes for the manufacture of tools and weapons occurred.

\subsection{Economic Impacts of Increasing Scarcity of Natural Resources for Producing Bronzes - Escalating Costs, Reduced Trade and Less Employment in Metallurgy}

Growing scarcity of raw materials for producing bronzes would have raised the cost for all UC tribes of their supply. Given the nature of their economies, a larger allocation of agricultural produce would have been needed to maintain the level of their bronze production and its quality. Consequently, the exchange value (price) of bronzes of a given quality would have risen. For example, as a result, in interregional trade more amber would have been required to purchase bronzes of particular quality, for instance, with a specified tin content.

It also seems likely that in some UC communities, the real cost in terms of the sacrifice of agricultural produce needed to supply bronzes rose sharply because the agricultural surplus fell (Tisdell and Svizzero, 2018). In these cases, growing scarcity of agricultural produce and of raw materials for bronze production increase simultaneously. Therefore these communities faced two types of burden.

Bronzes and materials for bronze-making were central constituents for the engagement of the UC tribes' interregional trade. Bronzes were traded for amber, furs from northern Europe and for gold. The declining ability of followers of the UC to produce bronzes (particularly, those with siginificant tin content) and the increased cost of bronze stymied this trade. The south-north trade passing through

\footnotetext{
${ }^{4}$ The Bell Beakers already used copper but tin bronze was a EBA phenomenon. 
the Polish trade corridor occupied by the UC tribes dwindled and eventually disappeared because the trade became uneconomic. However, alternative trade routes outside the territories occupied by the UC tribes opened up (Czebreszuk, 2007).

\subsection{The Bronze Sector Crisis}

Even though the Únětice economy was mainly based on mixed farming, i.e. the growing crops and the raising livestock, the bronze sector would have employed a large part of the population (Bartelheim, 2016a: 146). Indeed, prospecting for, extracting, processing, and smelting of ores, the alloying of metals as well as the metalworking process (working, casting, finishing) require tremendous organization (Harding, 2000: 234-235; Ottaway and Roberts, 2008). In addition to people directly connected to the bronze production process, other communities who were providing foodstuffs, wood and transport to miners and smiths were also indirectly linked to the bronze sector (Szeverenyi, 2004).

The reduction in materials for the production of bronze would have had several negative consequences for employment. Most likely there would have been a reduction in the numbers employed in bronze production and in the bronze-related trade. This would have especially affected a part of the population since some increased specialization in employment occurred, e.g. bronze smiths, those involved in the trade and transport of bronze products and related trades. In the academic literature there is still controversy over who were the people involved in bronze production. Possibly they could have been occupied either full-time or part time in this activity, depending, for instance, on the seasons. In any case, they would have had less employment and less income due to the bronze sector crisis. One option for some of them, in order to recover their living standards, would have been to emigrate, and this might have contributed to the collapse of the UC.

\subsection{The Socio-Cultural Significance of Bronzes to UC Tribes}

Although some limited utilitarian use of bronze occurred, e.g. the production of pins for costumes, bronze was mainly used to supply prestige consumption goods, not producer goods, during the EBA. The possession of bronzes was used to mark and reinforce social distinction, within and between UC tribes. Trade in bronzes enabled prestige items such as amber and gold to be obtained. These were pure prestige goods and played an important part in signalling social distinction. The interregional bronze-related trade also enabled contacts to be established and maintained by UC tribes over a wide geographical area (Czebreszuk, 2007). This would have helped in the interregional diffusion of ideas, and therefore helped to strengthen the superiority of the elite. The decrease of bronze production as well as of the income generated by it would have had several negative impacts from a socio-cultural point of view. The deposition of valuable objects (including bronzes) in graves would have declined. It would have become increasingly difficult to mark social distinctions by the possession and display of prestige goods, particularly in the case of persons of lower rank. In other words, upward social mobility would have been more difficult to achieve. This may have generated social gloom and negative economic feelings. Since some bronzes were possibly connected with religious observances, the bronze sector crisis may have had adverse religious consequences. This would have been so for religious practices in which the availability of bronzes was closely connected (Szeverenyi, 2004: 2627).

\section{THE GEOGRAPHICAL ORIGINS OF COPPER AND TIN ORES: IMPORTED VS LOCAL?}

Bronze is an alloy obtained by the small addition of any various metals (arsenic, tin,...) to copper. However, when we talk about bronze, we usually - and implicitly - refer to tin-bronze.

\subsection{Copper Ores}

Copper ores are present in the Erzgebirge and this favors the assumption of the exploitation of local surface sources of metal ores in the Early Bronze Age (Harding, 2000: 197-199; Bartelheim, 2013, 2016a), as has been documented, for instance, in the territory of south-west Slovakia (Bátora, 1991: 106-107). However, for other authors there seems to be "no evidence for prehistoric mining in the Erzgebirge, but the Rammelsberg deposit in the Harz Mountains might have supplied some of the copper," (Niederschlag et al., 2003, p. 61). Lutz and Pernicka (2013, p. 125) have confirmed such results in their study of the prehistoric copper sources of the Eastern Alps. Indeed, they have found an excellent match between all objects of the Nebra hoard and the Sky Disk of Nebra and trace elements 
(lead isotope ratios) in ores and prehistoric slags from the Mitterberg district. This is not a surprising result, because even for copper objects found in Central Europe and dating from the Late NeolithicEneolithic, copper smelting has never been unequivocally documented. This is so despite copper metallurgy flourishing in southeastern Europe in this period, with copper mining being attested to at Rudna Glava in Serbia and at Ai Bunar in Bulgaria (Tylecote, 2002: 12; Höppner et al., 2005).

Because the Harz mountains are located on the northwestern border of the territory associated with the Unĕtice culture, while the Erzgebirge mountains are centrally located in this territory (Niederschlag et al., 2003, Fig.1, p. 63), the Uněticians may have made use of copper ores from these sources. Unworked copper (e.g. ingots) may have been imported by some Únětice settlements for which the importers exchanged amber, textiles and even finished bronzes. Nevertheless, several scholars (for example, Jirán et al., 2013: 804) claim that the main source of copper used by followers of the UC was from the Alps and usually imported in the form of ingots. Rassmann (2011) has estimated that, for the end of the EBA, the amount of metal which circulated in the society at one time for a population of 10.000 persons was about $270 \mathrm{~kg}$, i.e. less than what was commonly thought. $\mathrm{He}$ concludes that a small number of societies in Central Europe could have produced the needed copper. However, this conclusion does not necessarily follow.

\subsection{Tin Ores}

Since the production of tin-bronze requires tin, and since tin deposits are very rare compared to copper, tin was a strategic raw material of the Bronze Age. Therefore, there is a long tradition of debates in the academic literature about the geographical origins of tin (Harding, 2000; Haustein et al., 2010). Tin bronze first appeared in the Near East (from Mesopotamia to Egypt), yet this region (which consists of plains) has no (obvious and major) source of tin, hence the prevailing thought was that Afghanistan or central Asia were the only sources available to the ancient Near East even during the earlier formative third millennium B.C.. It was only during the late 1980s that excavations and archaeo-metallurgical investigations yielded the solution of a major enigma puzzling scholars for decades: tin mines were present in the central Taurus mountains (Yener et al., 1989). Thus, a tin supply was located in a non-exotic location, Turkey, where the earliest tin bronzes existed. Moreover, this also suggests that multiple tin sources could have been exploited in the Near East (even though their exploitation has left little to no archaeological evidence). A similar scenario seems likely regarding tin sources in Central Europe. Opposing views exist (see section 6) about the sources of tin used in Central Europe during the EBA (and onwards).

\subsection{Tin Isotope as a Fingerprinting Tool for the Provenance of Tin}

Given this long tradition of debates, it was tempting in the last decades to investigate if tin isotope ratios could provide a clue for the solution of the long discussed enigma of the provenance of tin used in the Bronze Age, and more specifically given our aim, the supply of tin in the European Early Bronze Age with four major regions of tin mineralisation, namely southwest England with Brittany, the Saxon-Bohemian Ore Mountains, the western Iberian peninsula and the Massif central in France. However, and despite recent advances (Berger et al, 2018), many questions especially regarding the behavior of tin isotopes during pyrometallurgical processes are still not satisfactorily answered. In an exploratory study (Nessel et al, 2015) it seemed that the deposits in southwest England and in the Ore Mountains could largely be distinguished with tin isotope ratios, and it seemed thus likely that the Unětice Culture used the local tin ores, even though there is no archaeological evidence of prehistoric tin mining in this region. This result has been qualified and even challenged in the sequel since with more data the overlap of the signatures of the tin isotopic composition of cassiterite from two major tin provinces in Europe (Cornwall and the Erzgebirge) increased, and then a clear differentiation is not possible (Brügmann et al, 2017).

\section{The DEVElopment OF BronZe Production AND THE USE Of TIN}

When we talk about bronze, we usually - and implicitly - refer to tin bronze. Nevertheless bronze can be produced with copper using alloys other than tin. There are two different hypotheses about the development of bronze production according to the metal alloyed with copper. Until recently, it was commonly believed that the process of bronze production process was - from a chronological point of view - linear and gradual, that is, a slow serial process. Such an "evolutionist" view is implicitly 
present in the relative chronology of the EBA introduced by Paul Reinecke (1924). He subdivides the EBA into two phases, A1 and A2, which reflect the growing ability to manage the new bronze technology. Almost all further chronological discussion has retained his view of a gradual development of the technology from the manufacture of bone and boar tusk pins to the first hammered metal objects consisting mostly of copper with hardly any tin in A1 up to perfectly alloyed bronze with $90 \%$ of copper and $10 \%$ of tin and refined casting techniques in A2. According to this vision, the first bronze produced in virtually all of Europe was an alloy of copper and arsenic. This seems to be logical since deposits of arsenic minerals are much more abundant than tin minerals. Furthermore, arsenic and copper minerals commonly occur together in sulphide deposits, and both weather to greenish oxide and carbonate minerals that can be difficult to distinguish (Cathro, 2005). It should be noted that ores of these metals other than tin (arsenic, antimony, zinc...) were present in several regions of Central Europe (Bátora, 1991; Harding, 2000: 198-201). Consequently, before 1800 B.C., followers of the UC were not dependent on imports to get these metals. The gradual shift to tin bronze $^{5}$ - a copper alloy containing around 8 to $12 \%$ tin - occurred because tin bronze has better "qualities" than bronze made from alloys with metals other than tin (Pare, 2000: 7).

According to Kienlin (2013: 420-421), in Central Europe, the move to tin bronze was a gradual process that only came to an end well into the second millennium B.C. (around 1800/1700 B.C.). So, from 2300 to $1800 / 1700$ B.C., it is likely that UC people were casting various alloys of copper with metals other than tin (arsenical copper, then fahlore copper). Therefore, and according to this evolutionist vision, it is only from 1800 B.C. onwards that UC people would have used tin to make bronze.

Such a linear and gradual view has been recently qualified by authors who consider that there was no sharp transition between the two EBA sub-periods, A1 and A2, but a complete overlap between the types of objects produced in these the two phases (Stockhammer et al., 2015). In other words, it is inaccurate to assume that the watershed of bronze production by UC tribes was 1800 B.C., with no or very few tin bronzes before that date and exclusively tin bronzes after that. This new assertion reinforces our conclusion (presented in section 6) since it implies that tin (i.e. placer tin) was already used before 1800 B.C. and therefore its exhaustion or severe diminution is more likely to have occurred when the UC was well established.

\section{The Source of Tin Ores: Underground Mined vs Collected from Alluvial DEPOSITS?}

Before we turn to these views, it is important to note that tin occurs in both primary deposits (which occur mainly within igneous intrusive rocks, such as granite) and secondary deposits or placers (which derive from the weathering and erosion of primary deposits). Cassiterite ${ }^{6}$ has a high specific gravity of 7.1 which is comparable to that of metallic iron, and also its hardness is comparable to that of quartz, so that it is highly resistant to abrasion and tends to concentrate in gravels and alluvial deposits (Darling, 2002: 58). Some scholars consider that the tin deposits of the Erzgebirge were of a hard rock type, resulting not in the formation of alluvial or placer cassiterite but in seams of cassiterite buried in granite rock deep beneath the surface of the earth and thus not accessible to a Bronze Age prospector. Therefore, and according to this view, as expressed by Mulhy (1985: 290), "the history of Saxo-bohemian tin was a history of hard rock mining (...) to go back not earlier than the twelfth century B.C." Others, such as Dayton (1971), consider that the existence of alluvial tin was possible in Central Europe and even that the streams of northern Bohemia may have carried them far from Central Europe (e.g. to southeast Europe, for instance, Serbia; Durman, 1997). Despite the use of upto-date investigation methods - such as the isotopic analysis of ores and metal objects - this debate is still present in the academic literature. On the one hand, and even though tin ores are present in the Erzgebirge, and as quoted by Earle et al. (2015), "There are also tin ores in Central Europe in the

\footnotetext{
${ }^{5}$ According to Merkl (2010, p. 20, footnote 4), "It has not been clarified whether there is a specific threshold marking the difference between naturally tin-bearing copper and copper deliberately alloyed by tin - so-called tin-bronze. Whilst before around 2000 B.C. copper artefacts generally do not contain more than around $4 \%$ tin, afterward copper artefacts contain significantly more than $4 \%$ tin."

6Cassiterite $(\mathrm{SnO} 2)$ is the more important tin ore, a naturally occurring oxide mineral which typically contains about $78,8 \%$ of tin.
} 
Erzgebirge, but so far no evidence of BA exploitation exists (Haustein et al., 2010)". Therefore, although they produced bronze items, the UC people did not develop tin mining during the EBA.

On the other hand they had access to local tin. As stated by Bouzek et al. (1989, p. 203) "...many small sources of metals, both tin and copper, were exploited, the former metal by washing from the river and creek beds. Though these sources were more modest than the British and Spanish tin supply, they seem to have served the Bohemian and Saxon Bronze Age cultures well". A "solution" to this debate seems to have been already provided by Childe's cautious comment (1929: 5), as quoted by Clark (1966: 195) who considered that tin in Central Europe was "not plentiful nor easily worked, but the weathered surfaces may once have contained alluvial 'pipes' now exhausted". In other words, tin was not mined but most likely won from alluvial stream deposits carrying tin-oxide minerals (Kienlin, 2013: 419; Niederschlag et al., 2003). Cassiterite is easier to find than arsenic because it is durable, dense and hard. This may help to explain the shift from arsenical copper to tin bronze. Cassiterite concentrates in stream channels (alluvial (placer) deposits) can be found by panning (Cathro, 2005). Bartleheim (2016a: 140-142) reports that the Krupka mining area (District of Teplice, North Bohemia) is one of the richest in tin ores within the Erzegebirge and that in preindustrial times its easily accessible placers reached down into the inhabited areas of north Bohemian lowlands. In addition, it is also possible that EBA miners used hushing, a method using a flood or torrent of water to reveal mineral ores. ${ }^{7}$ Due to its much easier minability in prehistoric times, the use of this secondary deposit type was more common than mining on primary cassiterite veins (Haustein et al., 2010: 826). As pointed out by Tylecote (2002: 18), "today, the greater proportion of all tin comes, as undoubtedly in early times, from alluvial or mined deposits of cassiterite." Similarly Harding (2000: 197) stresses that "distribution maps of ores sources for copper, tin, lead and gold (...) cannot show the multiplicity of small surface sources which for early metalworkers would have represented the first port of call for ore supplies."

\section{INDIRECT EVIDENCES OF TIN AND BRONZE SHORTAGES}

We have previously stressed that even though there is no archaeological record of tin mining in Central Europe during the EBA, it is very likely that some groups belonging to the Únětice culture were using local tin - and not imported - since they were able to exploit tin alluvial deposits from the Central European mountains. Moreover, it is likely that UC people produced various types of bronze from 2300 B.C. and onwards (i.e. long before the classical phase), including tin-bronze (Stockhammer et al., 2015).

Both conclusions allow us to draw inferences about the demise of the UC. First, the mining of placer tin did not leave any trace of prehistoric mining activity in the UC region. Although Niederschlag et al. (2003: 96) consider such explanation as an "unsatisfactory postulate", it seems to us a reasonable conclusion if one accepts the idea that ancient placer tin could have been exhausted by subsequent mining (Cathro, 2005) or covered by alluvial wash. Placer tin might have been exhausted "rapidly", i.e. after a few centuries of exploitation. Exhaustion of some ores was possible since it is a problem which occurred in the Middle and Late Bronze Age (Kristiansen and Larsson 2005: 134).

Although we have until now considered tin exhaustion, the complete exhaustion of tin sources is not a necessary condition for a tin crisis to occur. A tin shortage may occur if there is an excess of tin demand over its supply. What could be the logical consequences of such a shortage? Let us turn to an analysis of human behavior on both sides of the bronze market.

\subsection{The Reactions of Bronze Producers}

On the supply side, bronze producers may adopt one of the two following strategies. First they may try to maintain the production of a high-quality tin bronze (i.e. with an 8-12\% tin content). For such a purpose, one option is to recycle ${ }^{8}$ bronze items (Harding, 2000: 220). Some of the hoards belonged to those who collected scrap metal for re-smelting. Such a practice might be explained by the growing

\footnotetext{
${ }^{7}$ This method was used in order to obtain gold during the Roman period and has been described by Pliny the Elder (1855: book XXXIII, Chapter 21). Agricola (1556: 337-339) has even described how this method was used to get tin ores.

${ }^{8}$ As, for instance, it is well-documented by Karageorghis and Kassianidou (1999) for the Late Bronze Age in Cyprus.
} 
scarcity of metals - and especially of placer tin - as long as the demand of bronze products increased. A second option consists in importing tin from regions beyond the UC territories. Some evidence seems to support use of the latter option. Haustein et al. (2010: 830) state that "the tin-isotope ratio of the 'Himmelsscheibe von Nebra' will be presented: the value fits well with the bulk of investigated tin ores from Cornwall". However, this is insufficient evidence to conclude that tin was imported from Cornwall. If it was, it was probably in quite small amounts, because there is a very long distance between Cornwall and Central Europe. Furthermore, the disk $^{9}$ itself could have been imported. Nevertheless, it is possible that, when UC people were confronted to placer tin shortages, they imported small quantities of tin from abroad.

The second possible strategy of suppliers is to produce low-quality bronze products. Metallurgists begin doping metal, meaning they add minimal quantities of tin, or turn to natural copper only; put simply, they are cheating. Such a method has been documented by Pare (2000: 19) for the classic UC phase. In the "central area" of the UC territory, there are roughly equal numbers of artefacts containing above and below two percent of tin, while in the "peripheral regions" only $21 \%$ of objects contained more than two percent of tin.

\subsection{The Reactions of Bronze Consumers}

On the demand side, bronze objects were probably too expensive and therefore out of reach for commoners, i.e. they were restricted to the elite. When tin (and most likely copper) became scarcer, the price of bronze objects increased. As a result, some people would have been tempted to obtain bronze items by illegal means such as robbery. Such robbery may be of graves (since adopters of UC were often buried with bronze artefacts) or houses containing bronze objects. Facing such a threat, the owners of bronze objects would be motivated to secure their wealth, by hoarding. ${ }^{10}$

For the elite, even though the price of bronze products increases as a result of the tin crisis, they however still want to own high-quality bronze products because they are the symbol of their social status. Halberds for instance (associated with UC tribal elites and power) are always made according to high standards. One solution for the elite could be therefore to extract - as a tax in kind or tribute ${ }^{11}$ - an additional surplus consisting of bronze products in order to recycle them. Once again and in reaction to this 'legal collection' organized by the elite, some people may have been tempted to hide bronzes. This would have been another motive for the hoarding behavior.

\section{Fuel Used in the Metalworking Process}

\subsection{Ore Extraction and the Demand for Wood}

Unlike tin or gold, copper does not occur in concentrated form in secondary drift or alluvial deposits. Thus, copper ore exploitation in prehistory was only possible in hard rock and was primarily accomplished by fire-setting (Weisgerber and Willies, 2001) which necessitated the burning of large amounts of wood. Wood could be used for the roasting process and for the mining technique of firesetting, in which fire was used as a method to break up ore-bearing rock into manageable pieces.

One way to quantify the potential demand for fuel wood is to conduct archaeological experiments. There are two main groups of factors that affect rock exploitation. First, factors that describe the morphology of the rock, e.g., chemical and mineral composition of the rock, grain size, thermal expansion ratio and internal structure. Second, factors related to the fire-setting application, e.g. characteristics of the fuel wood (green or seasoned wood, size, round or split wood, water content, and species), temperature, archaeological experience in the fire-setting technique, ventilation and construction of the wood stack. However, assuming various rock-to-wood weight ratios, it seems that the demand of wood for fire-setting activities was limited, unlike that for charcoal and would not have made great demands on local forests (see e.g. Pichler et al., 2013).

\footnotetext{
${ }^{9}$ The Nebra sky disk was buried ${ }^{9}$ around 1600 B.C. (Haustein et al., 2010, p. 830), i.e. at the period during which the UC started to vanish.

${ }^{10}$ Of course hoards are of various kinds (personal, collective) and hoarding is consistent with various purposes (votive hoard, founder hoard, trader hoard...). Thus, we simply highlight here what could be one of these purposes.

${ }^{11}$ Even though we do not know how the UC elite managed to get their hands on an economic surplus.
} 


\subsection{The Smelting Process and the Compulsory Use of Charcoal}

While wood could be used for the roasting process ${ }^{12}$ and for the mining, the smelting process of copper ores ${ }^{13}$ required the use of charcoal as a fuel since no other fuel commonly used in ancient times would burn hot enough to smelt copper. Indeed, wood burns at a lower temperature than charcoal (it has half of charcoal's caloric value) so charcoal was a more efficient fuel for metallurgical activities (Harding, 2000: 217; Tylecote, 2002) and was necessary for the smelting process since separating the copper from the gangue was possible only by smelting, using furnaces that were able to reach at least $1,089^{\circ} \mathrm{C}$ (Ottaway and Roberts, 2008: 205).

Charcoal production requires a significant expenditure of labor and wood. The latter needs to be cut and dried for up to several months, then used to construct a charcoal stack. Hardwoods were preferred for metallurgical uses because they contain more carbon and are stronger and more durable. Only about $10-20 \%$ of the wood used in a charcoal stack becomes charcoal, and large amounts of charcoal are required to make a significant amount of copper using ancient techniques (Craddock, 1995). In fact, different and subsequent ratios have to be considered in order to approximate the deforestation impact of the production of a given weight of metal. These ratios are: surface of forest/number of trees; number of trees/volume or weight of wood; weight of dried wood/weight of charcoal; weight of charcoal/weight of ores smelted; weight of ores smelted/weight of metal produced. Given the large number of these ratios on the one hand, and the large number of factors influencing these ratios on the other hand, the deforestation impact of bronze production can only be roughly approximated. While for mining, Pichler et al. (2013) derived a generalised rock-to-wood weight ratio with a range of approximately 0.7 to 1 , according to Craddock (1995, p. 193) the smelting process required $122 \mathrm{~kg}$ of charcoal for $1 \mathrm{~kg}$ of copper. Harding (2000: 217) reports that "It has been estimated that to produce 5 $\mathrm{kg}$ of copper metal one would need at least $100 \mathrm{~kg}$ of charcoal, which would in turn have required $700 \mathrm{~kg}$ of timber." Since charcoal is about 10 to $20 \%$ of the dried wood used for its production, it is certain that forests were severely and negatively impacted by the procurement of the fuel needed for the smelting process. Suitable fuel supplies may even have been locally exhausted after a few decades. It should also be kept in mind that fuel was needed for smelting tin and for re-smelting copper and tin ingots and bronze objects. Trees were the ultimate source of this fuel. The use of trees for these purposes added to deforestation.

In addition to the previous conclusion, we have to remind ourselves that the UC tribes were the first bronze producers in Central Europe. In other words, they did not have a precise knowledge of the various factors influencing the smelting process, such as the measure of the temperature into the furnace, the chemical composition of ores or the involuntary presence of fluxes. Puziewicz et al. (2015) provides XRF analysis of Unětice culture ornaments. They confirm the chemical variation of their composition and their typically dendritic metal microstructure which suggests rather poor control of the smelting and solidification process (compared to bronze artefacts of the subsequent Urnfield culture). In other words, UC tribes were learning how to produce bronze alloys through a trial-anderror process and were probably consuming much more fuel than modern archaeological experiments of the ancient smelting process suggest.

\section{Deforestation AND Shortages of Suitable Fuel}

By the time the Bronze Age was well under way, wood was being consumed on a scale that could not possibly be sustained on a long-term basis. As pointed out by Szeverenyi (2004: 20), deforestation due to opening up arable land and pasture reached its peak in the Late Neolithic and EBA during the phase of initial occupation of various environmental niches. In addition to the impact of agropastoralism, mining, smelting, metal-working, ship-building, pottery-making, construction industries and the exploitation of salt brine, all created massive demand for wood for fuel, and wood was used for almost all domestic fuel. Fuel procurement and fuel use in metallurgical activities by UC tribes would obviously have had a major environmental impact in metal-producing regions, including deforestation, soil erosion, and the destruction of habitats for many plant and animal species.

\footnotetext{
${ }^{12}$ Roasting consisted of calcinating the ore by lighting fires on ore collected in piles in open areas.

${ }^{13}$ Since cassiterite, the dominant tin ore, melts at only 600 degrees Celsius.
} 


\subsection{Metal Production and Deforestation}

Such long-term damage ${ }^{14}$ to the natural environment is, for instance, clearly documented for the island of Cyprus. ${ }^{15}$ Constantinou (1992) estimates that the island of Cyprus must have been deforested up to sixteen times in a 3,500 year period in order to produce the charcoal required to make the estimated four million tons of ancient slag known on the island. Similarly it is suspected that the decline of Çatal Höyük (6500 B.C.; modern Turkey) - where metalworking was marginal - is probably related to deforestation since the almost universal use of pottery and pottery kilns, plaster and terrazzo, would have had a significant negative impact on local woods and forests. The great silver mines of Laurion, near Athens, seem to have encountered the same difficulty. Wertime (1982) estimated on the basis of 3500 tons of silver and 1.4 million tons of lead production for classical Athens over perhaps 300 years, that the Laurion mines had consumed 1 million tons of charcoal and 2.5 million acres of forest. More generally, the role of deforestation as a contributor to social collapse is even more likely to have occurred in the Levant ${ }^{16}$ and the drier Mediterranean countries than in Central Europe. In the former areas, forests were less dense than in Europe and mining led to an irreversible change in the vegetation and landscape.

\subsection{The Multiple Causes of Deforestation}

Of course, deforestation occurred before the production of metals, i.e. from the Neolithic period onwards. Usually, the landscape was opened up by fire to establish space for agriculture and livestock farming. Several archaeological indicators of their landscape changes are available. In addition the Neolithic package also includes pottery, which is another user of pyrotechnology and thus another contributor to deforestation. Salt production is clearly documented in Central Europe since the Early Neolithic and the most common procedure of salt winning was brine evaporation, which also requires large quantities of wood for the boiling pans (Saile, 2012). In addition to these multiple causes, the deforestation process was reinforced by the production of metals indirectly through the establishment of the farmsteads which reflected the expansion of settlement activities in mining areas, and directly, as previously explained, through the use of wood and charcoal as fuel sources of the metal along the chaîne opératoire. It is thus likely that in the vicinity of ore mining, beech trees were probably felled over a wide area because fire from beech charcoal was suited to the production of metals.

\subsection{Deforestation and the Fate of the Únětice}

In the case of UC tribes, deforestation around 1600 B.C. is attested to by the distribution of the pollen profiles (Kneisel, 2012: 227; Müller, 2012). ${ }^{17}$ It is therefore quite likely that the bronze production declined because the fuel costs had risen to the point where this production had become increasingly uneconomic. Reduced availability of supplies of suitable fuel for extracting tin and copper from gangue near the source of mining ores may have eventually resulted in short supply of tin and copper. This would have impeded bronze production. When fuel became scarce in the vicinity of mining areas, 'virgin' tin and copper ores would have had to be transported to places where fuel was available or fuel would have to be carted to the area of mining of the ores. This would have added considerably to costs.

\section{CONCLUSION}

After 700 years of existence and prosperity, the Únětice culture disappeared in a few decades. Why this happened is intriguing. The considerable economic prosperity of UC tribes was mainly based on the Neolithic package typical of Central Europe, i.e. diversified agriculture including the cultivation

\footnotetext{
${ }^{14}$ It was also reinforced by grazing, particularly by goats.

${ }^{15}$ The name 'copper' for the metal in all Western European languages is derived from the Latin aescyprium which means "Cypriot copper." See Bartelheim (2016b) for a presentation of prehistoric metallurgy on Cyprus.

${ }^{16}$ In the Epic of Gilgamesh, the earliest epic poetry that has survived, Gilgamesh (a Sumerian, king of Uruk around 2700-2500 B.C.) and his companion go off to cut down a cedar forest, braving the wrath of the forest god Humbaba, who has been entrusted with forest conservation. This led to the loss of Gilgamesh's immortality which may be a literary reflection of the realization that Sumeria could not be sustained owing to deforestation and the shortage of wood.

${ }^{17}$ It should be noted that even though Bruszczewo - the site considered by Kneisel (2012) and Müller (2012) - is situated in the Northern European Great Plain, far away from any mining area, evidence of smelting ores and bronze production have been found at this site.
} 
of several cereals and pulses, and animal husbandry - mainly cattle and pigs. Moreover, these tribes had a pottery industry and were involved in a long-distance trade network, from Northern to Southern Europe, in which mainly prestige/luxury goods (e.g. amber, furs, gold...) were exchanged. More than anything else, the UC tribes were the first bronze producers of Central Europe, an activity providing wealth and power to their elite as well as labor for some of its populations.

Despite this, this culture suddenly disappeared without obvious reasons. No archaeological evidence has been found which is consistent with some of the usual explanations of social collapses, such as war, disease or natural disaster. Moreover, a few decades after its disappearance, new cultures - the Tumulus culture on the west and the Trzciniec culture on the east - appeared in the region formerly occupied by followers of the UC. Consequently, we favor an endogenous explanation of the UC collapse. We have argued that this collapse was primarily a result of the lack of natural resource sustainability due to economic activity (economic growth). Elsewhere (Tisdell and Svizzero, 2018), we have described how the natural resource base of agriculture (in the post-classical UC period) altered adversely as a result of agricultural practices. Increasing populations also placed additional pressures on agriculture. As a result, the agricultural surplus (the main source of the economic surplus) available to UC people fell, at least in Silesia, and probably in many other areas. This appears to have contributed to the depopulation of some UC settlements and had adverse social and cultural consequences as well (Tisdell and Svizzero, 2018).

In this article, we have focused on endogenous development as a contributor to the disappearance of the UC, namely the increasing scarcity of raw materials (and natural resources) for the production of bronzes. We have demonstrated that bronze production, the hallmark of the UC as well as its source of power, was also its weakness. This is so because in order to produce bronze, UC people were using placer tin (either obtained directly or indirectly) which was rapidly exhausted or became extremely scarce. Furthermore, the production of bronze required huge quantities of wood and charcoal which led, after a few centuries, to the deforestation of much of the UC area and those areas from which it obtained copper supplies. Unsustainable use of these natural resources (for bronze production) may have contributed to the collapse of the UC culture. This, together with falling agricultural productivity, is not easily reversed and may well have resulted in the abandonment of UC settlements (Tisdell and Svizzero, 2018).

\section{REFERENCES}

[1] Agricola, G. (1556)[1912], De Re Metallica. Translated by H.C. Hoover and L.H. Hoover. 1st English ed. London: The Mining Magazine.

[2] Bartelheim, M. (2009), Elites and metals in the Central European Bronze Age. In: T. L. Kienlin, B. W. Roberts (Eds.): Metals and societies: studies in honour of Barbara S. Ottway. Pp. 34-47. Rudolf Habelt, Bonn.

[3] Bartelheim, M. (2013), Innovation and tradition. the structure of early metal production in the North Alpine region. In: S. Burmeister, S. Hansen, M. Kunst, Müller-Scheeßel (Eds.): Innovative technologies and social change in prehistory and antiquity. Pp. 169-180. Marie Leidorf, Rahden, Westfalia.

[4] Bartelheim, M. (2016a), Metals as resources in the Early Bronze Age of Bohemia and Moravia, In: M. Bartelheim, B. Horejs, R. Krauß (Hrsg.), Von Baden bis Troia - Ressourcennutzung, Metallurgie und Wissenstransfer. Eine Jubiläumsschrift für Ernst Pernicka. Oriental and European Archaeology 3, Rahden/Westf., Verlag Marie Leidorf, 139-152.

[5] Bartelheim, M. (2016b), Prehistoric Metallurgy on Cyprus. In L. Summerer/H. Kaba (Hrsg.), Northern Face of Cyprus. New Studies in Cypriot Archaeology and Art History, Istanbul, Ege Yayinlari, 39-50.

[6] Bátora, J. (1991), The reflection of economy and social structure in the cemeteries of the Chlopice-Veselé and Nitra cultures, Slovenska Archeologia, 39(1-2), 91-142.

[7] Bátora, J. (2009), Metallurgy and early Bronze Age fortified settlements in Slovakia, Slovenska Archeologia, 57(2), 195-219.

[8] Bátora, J. A.et al.(2012), The rise and decline of the Early Bronze Age settlement Fidvár near Vráble, Slovakia. In J. Kneisel, W. Kirleis, M. Dal Corso, N. Taylor and V. Tiedtke (eds.), Collapse or Continuity? Environment and Development of Bronze Age Human Landscapes (Vol. 1, pp. 111-129), Bonn: Verlag Dr Rudolf Habelt GmbH.

[9] Berger, D., E. Figueiredo, G. Brügmann and E. Pernicka (2018), Tin isotope fractionation during experimental cassiterite smelting and its implication for tracing the tin sources of prehistoric metal artefacts. Journal of Archaeological Science 92: 73-86. 
[10] Bouzek, J.D. Koutecky, and K. Simon (1989), Tin and prehistoric mining in the Erzgebirge (Ore Mountains): some new evidence, Oxford Journal of Archaeology, 8, 203-212.

[11] Brügmann, G., D. Berger, C. Frank, J. Marahrens, B. Nessel, E. Pernicka (2017), Tin isotope fingerprints of ore deposits and ancient bronze. In P.Newman (ed), The tinworking landscape of Dartmoor in a European context - Prehistory to 20th century. Papers presented at a conference in Tavistock, Devon, 6-11 May 2016 to celebrate the 25th anniversary of the DTRG. Dartmoor Tinworking Research Group.

[12] Cathro, R.J. (2005), Tin deposits and the early history of bronze. CIM Magazine/bulletin, 98(June-July). Retrieved from http://www.aditnow.co.uk/documents/personal-album-272/tin-deposits-and-the-earlyhistory-of-bronze.pdf

[13] Childe, V.G. (1929), The Danube in Prehistory, Oxford: Clarendon Press.

[14] Clark, J.G.D. (1966), Prehistoric Europe: The Economic Basis, Stanford, CA: Stanford University Press.

[15] Constantinou, G. (1992), Ancient copper mining in Cyprus. In A. Marangou and K. Psillides (eds.), Cyprus, Copper, and the Sea (pp. 43-76), Nicosia: Government of Cyprus.

[16] Craddock, P.T. (1995), Early Metal Mining and Production, Washington, DC: Smithsonian Institution Press.

[17] Czebreszuk, J. (2007), Amber between the Baltic and the Aegean in the third and second millennia B.C. (an outline of major issues), Aegaeum Liege, 27, 363-370.

[18] Czebreszuk, J. (2013), The Bronze Age in Polish Lands. In H. Fokkens and A. Harding (eds.), The Oxford Handbook of the European Bronze Age (pp. 767-786), Oxford: University Press.

[19] Dayton, J.E. (1971), The problem of tin in the ancient world, World Archaeology, 3, 49-71.

[20] De Navarro, J.M. (1925), Prehistoric routes between Northern Europe and Italy defined by the amber trade, The Geographical Journal, 66(6), 481-503.

[21] Diamond, J.M. (2005), Collapse: How Societies Choose to Fail or Succeed, New York: Viking Press.

[22] Drews, R. (1993), The End of the Bronze Age: Changes in Warfare and the Catastrophe ca. 1200 B.C., Princeton, NJ: Princeton University Press.

[23] Durman, A. (1997), Tin in southeastern Europe? Opvscula Archaeologica, 21, 7-14.

[24] Earle, T. (2002), Bronze Age Economics:The Beginnings of Political Economies, Boulder, CO: Westview.

[25] Earle, T.,Ling, J., Uhnér, C., Stos-Gale, Z., and Melheim, L.(2015), The political economy and metal trade in Bronze Age Europe: understanding regional variability in terms of comparative advantages and articulations, European Journal of Archaeology, 18(4), 633-657.

[26] Ekholm, K. (1980), On the limitations of civilization: the structure and dynamics of global systems. [journal article], Dialectical Anthropology, 5(2), 155-166.

[27] Ernée, M. (2012), Bernstein in der böhmischen Aunjetitz-Kultur - zu den Anfängen der Bernsteinstrasse, Památky Archeologické CIII, 71-172.

[28] Harding, A.F. (2000), European Societies in the Bronze Age, Cambridge: Cambridge University Press.

[29] Haustein, M., C. Gillis, and E. Pernicka (2010), Tin Isotopy - a new method for solving old questions, Archaeometry, 52(5), 816-832.

[30] Höppner, B., Bartelheim, M., Huijsmans, M., Krauss, R., Martinek, K.-P., Pernicka, E. and Schwab, R. (2005), Prehistoric copper production in the Inn Valley (Austria) and the earliest copper in Central Europe, Archaeometry, 47(2), 293-315.

[31] Jaeger, M., J. Czebreszuk, J. Müller, and J. Kneisel (2015), Metal finds. In J. Czebreszuk, J. Müller, M. Jaeger and J. Kneisel (eds.), Bruszczewo IV. Natural Resources and Economic Activities of the Bronze Age People (pp. 227-234), Bonn: Verlag Dr. Rudolf Habelt GmbH

[32] Jaeger, M. (2012), Kościan group of Únetice culture and fortified settlement in Bruszczewo. their role in micro- and macro-regional exchange. In M. Jaeger, J. Czebreszuk and K. P. Fischl (eds.), Enclosed Space Open Society, Contact and Exchange in the Context of Bronze Age Fortified Settlements in Central Europe (pp. 167-176), Poznań-Bonn: SAO/SPEŚ 9.

[33] Jiráň, L., Salaš, M. and Krenn-Leeb, A. (2013), The Czech Lands and Austria in the Bronze Age, In H. Fokkens and A. Harding (eds.) The Oxford Handbook of the European Bronze Age (pp. 781-812), Oxford: Oxford University Press.

[34] Karageorghis, V. and V. Kassianidou (1999), Metalworking and Recycling in Late Bronze Age Cyprus the Evidence from Kition, Oxford Journal of Archaeology, 18(2), 171-188.

[35] Kienlin, T.L. (2013), Copper and bronze: Bronze Age metalworking in context. In H. Fokkens and A. Harding (eds.), The Oxford Handbook of the European Bronze Age (pp. 414-436), Oxford: Oxford University Press. 
[36] Kneisel, J. (2012), The problem of the middle Bronze Age inception in Northeast Europe or: did the Únětice society collapse? In J. Kneisel, W. Kirleis, M. D. Corso, N. Taylor and V. Tiedtke (eds.), Collapse or continuity? Environment and Development of Bronze Age Human Landscapes (Vol. 1, pp. 209-234), Bonn: Verlag Dr. Rudolf Habelt GmbH.

[37] Kristiansen, K. and Larsson, T. (2005), The Rise of Bronze Age Society: Travels, Transmissions and Transformations. Cambridge: Cambridge University Press.

[38] Lutz, J. and E. Pernicka (2013), Prehistoric copper from the Eastern Alps, Open Journal of Archaeometry, $1(25), 122-126$.

[39] Merkl, M.B. (2010), Bell Beaker metallurgy and the emergence of fahlore-copper use in Central Europe, Interdisciplinaria Archaeologica 1, 19-27.

[40] Moucha, V. (1963), Die periodisierung der Úněticer kultur in Böhmen. Sborník Československé Společnosti Archeologické, 3, 9-60.

[41] Muhly, J.D. (1985), Sources of tin and the beginnings of bronze metallurgy, American Journal of Archaeology, 89(2), 275-291.

[42] Müller, J. (2012), Changes in the Bronze Age: social, economical and/or ecological causes? In J. Kneisel, W. Kirleis, M. D. Corso, N. Taylor and V. Tiedtke (eds.), Collapse or Continuity? Environment and Development of Bronze Age Human Landscapes (Vol. 1, pp. 257-266). Bonn: Verlag Dr. Rudolf Habelt GmbH.

[43] Nessel, B., Brügmann, G., Pernicka, E., (2015), Tin isotopes and the sources of tin in the Early Bronze Age Únetice culture. In: Ortiz Hunt, M.A. (Ed.), XV Congreso internacional sobre patrimonio geologico y minero. XIX Sesion científica de la sedpgym, pp. 11e28. Logrosan (Caceres, Extremadura), 25-28 de septiembre de 2014, Logrosan.

[44] Niederschlag, E., Pernicka, E., Seifert, Th. and Bartelheim, M.(2003), The determination of lead isotope ratios by multiple collector Icp-Ms: a case study of early Bronze Age artefacts and their possible relation with ore deposits of the Erzgebirge, Archaeometry, 45(1), 61-100.

[45] Ottaway, B.S. and Roberts, B.W. (2008), The emergence of metallurgy. In A. Jones (ed.) Prehistoric Europe: Theory and Practice, 193-225. London: Blackwell.

[46] Pare, C.F.E., (2000), Metals Make The World Go Round. The Supply and Circulation of Metals in Bronze Age Europe, Oxford: Oxbow books.

[47] Pichler, T., Nicolussi, K., Goldenberg, G., Hanke, K., Kovács, K. and Thurner, A. (2013), Charcoal from a prehistoric copper mine in the Austrian Alps: dendrochronological and dendrological data, demand for wood and forest utilisation. Journal of Archaeological Science, 40(2), 992-1002.

[48] Pliny the Elder (1855), The Natural History. Book XXXIII, chapter 21, available online at http://www.perseus.tufts.edu/hopper/text?doc=Perseus:abo:phi,0978,001:33 (Accessed June 29, 2017).

[49] Pokutta, D. A. (2013), Population Dynamics, Diet and Migration of the Únĕtice Culture in Poland. Department of Historical Studies, University of Gothenburg, Gothenburg.

[50] Puziewicz, J., Baron, J., Ntaflos, Th. and Miazga, B. (2015), The composition and microstructural variation of the Bronze Age metal ornaments from Lower Silesia (South-West Poland): chemical analytical and archaeological aspects, Archaeometry, 57(4), 653-676.

[51] Rassmann, K. (2011), Metalverbrauch in der frühen Bronzeeit Mitteleuropas. Produktion, Zirkulation un Konsumption frühbronzezeitlicher Metallobjekte als Untersuchungensgegenstände einer archäologishen Wirtschaftsgeschichte. In S. Hansen and J. Müller (eds.), Sozialarchäologische Perspektiven: Gesellschaftlicher Wandel 5000-1500 v.Chr. Zwischen Atlantik und Kaukasus, 341-363. Berlin: Verlag Phillip von Zabern.

[52] Reinecke, P. (1924), Zur chronologischen Gliederung der süddeutschen Bronzezeit. Germania, 8, 43-44.

[53] Roberts, B.W., C.P. Thornton, and V.C. Pigott (2009), Development of metallurgy in Eurasia. Antiquity, 83, 112-122.

[54] Saile, T. (2012), Salt in the Neolithic of Central Europe: production and distribution. In V. Nikolov and K. Bacvarov (eds.), Salz und Gold: die Rolle des Salzes im prähistorischen Europa / Salt and Gold: The Role of Salt in Prehistoric Europe (pp. 225-238). Provadia, Bulgaria: Provadia \& Veliko Tarnovo. (Proceedings of the International Symposium (Humboldt-Kolleg) available at http://www.uni-regensburg.de/ philosophie-kunst-geschichte-gesellschaft/vor-und-fruehgeschichte/medien/saile_2012.pdf)

[55] Stockhammer, P.W., Massy, K., Knipper, C., Friedrich, R., Kromer, B., Lindauer, S., Radosavljević, J., Wittenborn, F. and Krause, J. (2015), Rewriting the Central European Early Bronze Age chronology: evidence from large-scale radiocarbon dating. PLoS ONE, 10(10), e0139705.

[56] Szeverény, V. (2004), The Early and Middle Bronze Ages in Central Europe, in Ancient Europe; 8000 B.C. - 1000 A.D. Encyclopaedia of the Barbarian World, vol 2: 20-30. P. Bogucki and P.J. Crabtree (eds.), New York: Charles Scribners \& Sons. 
[57] Tisdell, C.A. and S. Svizzero (2015), The collapse of some ancient economies due to unsustainable mining development, Economic Theory, Applications and Issues, Working Paper No. 72, Brisbane: School of Economics, The University of Queensland.

[58] Tisdell, C.A., and Svizzero, S. (2018), The economic rise and fall of the Silesian Únětice cultural population: a case of ecologically unsustainable development? Anthropologie - International Journal of Human Diversity and Evolution, 56(1): 21-38. DOI: https://doi.org/10.26720/anthro.17.05.10.1

[59] Tylecote, R.F. (2002), A History of Metallurgy. 2nd edition, Maney Publishing for the Institute of Materials.

[60] Weisgerber, G. and L. Willies (2001), The use of fire in prehistoric and ancient mining-firesetting. Paléorient, 26(2): 131-149.

[61] Wertime, T.A. (1982), Cypriot metallurgy against the backdrop of Mediterranean pyrotechnology: energy reconsidered. In J. D. Muhly, R. Maddin and V. Karageorghis (eds.), Early Metallurgy in Cyprus, 4000500 B.C. (pp. 351-362), Nicosia, Cyprus: Department of Antiquities.

[62] Yener, K.A. et al. (1989), Kestel: An early Bronze Age source of tin ore in the Taurus mountains, Turkey, Science, 244(4901), 200.

Citation: Serge Svizzero. "The Demise of the Únĕtice Culture due to the Reduced Availability of Natural Resources for Bronze Production" International Journal of Research in Sociology and Anthropology (IJRSA), vol 4, no. 3, 2018, pp. 1-14. doi:http://dx.doi.org/10.20431/2454-8677.0403001.

Copyright: (C) 2018 Authors. This is an open-access article distributed under the terms of the Creative Commons Attribution License, which permits unrestricted use, distribution, and reproduction in any medium, provided the original author and source are credited. 